\title{
DIFFERENCES BETWEEN SIMPLE AND CHOICE REACTION TIME AMONG YOUNG KARATE ATHLETES IN RELATION TO GENDER AND LEVEL OF TRAINING
}

\section{DIFERENCIAS DE TIEMPO DE REACCIÓN SIMPLE Y ELECTIVO EN LOS JÓVENES KARATECAS DE AMBOS SEXOS DE DISTINTO NIVEL DE ENTRENAMIENTO}

\author{
Vesna Vukovići ${ }^{1}$ Stefan Marković ${ }^{1}$, Nenad Koropanovski', Miroslav Milovanović ${ }^{1}$, Milivoj Dopsaj \\ ${ }^{1}$ Faculty of Sport and Physical Education, University of Belgrade, student of DAS, Serbia \\ ${ }^{2}$ University of Criminal Investigation and Police Studies, Belgrade, Serbia \\ ${ }^{3}$ Faculty of Sport and Physical Education, University of Belgrade, Serbia \\ ${ }^{3}$ Institute of Sport, Tourism and Service, South Ural State University, Chelyabinsk, Russia
}

\begin{abstract}
Compared to adults, children have longer simple reaction time (SRT) and choice reaction time (CRT) to simple and choice visual stimuli. Based on the available data, it can be concluded that this occurrence could be due to correlation between age and the information processing speed. Other factors may have an impact, too, such as the shorter attention span which children may have. Some studies indicate that karate favors the development of cognitive functions, including the RT. Therefore, the aim of the current study was to determine whether there is a difference in simple and choice reaction time between boys and girls of preadolescent and early adolescent age on the basic and premastery level of karate training. Testing involved 78 participants divided into four subgroups, in accordance with the gender and the level of training, using a custom designed RT measuring software, developed in LabVIEW 2012 software package. A two-way analysis of variance (Two-way ANOVA) confirmed no differences between boys' and girls' SRT scores, while the significant differences were found at the mastery criterion subsample level. When it comes to CRT, the differences were found at the boys' subsample level, as well as between genders on the basic level of training. It cannot be stated with absolute certainty whether the acquired differences are the result of karate training, some other physiological and cognitive phenomena or the maturation process. Consequently, the futher research should involve a broader sample - the population of the physically inactive, as well as the children involved in other sports.
\end{abstract}

Key words: REACTION TIME / LEVEL OF TRAINING / YOUNG ATHLETES / KARATE /

\section{EXTRACTOS}

En comparación con los adultos, los niños tienen más lento tiempo de reacción (TR) simple (TSR) y electivo (TER) a un estímulo visual simple y electivo. Sobre la base de los datos de la literatura accesible se puede concluir que la razón podría ser la relación de la edad con la velocidad de elaboración de datos, pero también otros factores como, por ejemplo, la poca atención, pueden tener influencia. Algunas investigaciones indican que karate favorece el desarrollo de las funciones cognitivas, incluyendo también el TR. Por eso el objetivo del presente estudio ha sido establecer si entre los niños y las niñas de edad preadolescente y de adolescencia temprana, en nivel de entrenamiento de aprendices y pre maestros en karate, existen diferencias en el tiempo de reacción simple y electivo. Se hicieron pruebas en los 78 examinados divididos en cuatro subgrupos en relación con el sexo y el nivel de entrenamiento, aplicando un software especialmente diseñado para medir el TR, desarrollado en el paquete de programa LabVIEW 2012. Por el análisis de dos factores de variancia (Two-wayANOVA) se estableció que no hay diferencias expresadas para el TRS entre los niños y las niñas, pero son considerables en el nivel de submuestras según el criterio de maestría. En cuanto al TRE, las diferencias se establecieron en el nivel de submuestras de los niños, así como también entre los sexos en nivel de entrenamiento de aprendices. No se puede confirmar con seguridad si las diferencias obtenidas son la consecuencia de entrenamiento, o de algunos otros fenómenos fisiológico-cognitivos, es decir del proceso de maduración. Por eso las futuras investigaciones tendrían que abarcar una muestra más amplia - la población de los niños inactivos, como también de los niños incorporados en otros deportes.

Palabras claves: TIEMPO DE REACCIÓN / NIÑOS / KARATE / NIVEL DE ENTRENAMIENTO / SEXO 


\section{INTRODUCTION}

In many sports, maximum speed is not considered as a priority, while a maximum reaction speed usually is considered as an important factor for success (Vences de Brito \& Silva, 2011). The ability to spot and extract relevant information in conditions of spatial and time limitations makes a qualitative difference in the achievement between athletes of different level of training (Heirani, Vazini Taher, Soori, \& Rahmani 2012; Mori, Ohtani, \& Imanaka, 2002; Müller \& Abernethy, 2012). Additionally, there is a widespread belief that reaction time is one of the main factors of success in karate (Chaabene, Hachana, Franchini, Mkaouer, \& Chamari 2012; Vences de Brito \& Silva, 2011; Mori et al., 2002). In accordance with that, it is believed that the training tasks designed to minimize the reaction time to the opponent's activity could help development of perception skills and non-specific basic sensory functions of karate athletes (Mori et al., 2002; Vences de Brito \& Silva, 2011).

The reaction time (RT) is defined as a measure of speed of the perceptual-cognitive system (Jensen, 2006), expressed through the time elapsing between the beginning of the application of a stimulus and the response (Heirani et al., 2012). The two basic types of RT are distinguished: simple and choice. The simple reaction time involves one response to one stimulus under familiar conditions for the shortest time possible. Choice reaction time represents the fastest possible realization of motor response in conditions with an alternative stimulus introduced (Schmidt \& Lee, 1999). Specific characteristics of the sport have an imapct on the development of sensory-cognitive skills (Nuri, Shadmehr, Ghotbi, \& Moghadam 2012), whereas non-athletes, in comparison to athletes, achieve longer RT (Tanaka, Hasegawa, Kataoka, \& Katz, 2010; Youngen, 1959), regarding both visual and auditory stimulus (Atan \& Akyol, 2014). Regardless of applied stimulus, i.e. whether or not a sport-specific stimulus (e.g. sport-specific technique) was applied in the study, the athletes achieved a shorter RT for motor response (Tanaka et al., 2012; Youngen, 1959; Atan \& Akyol, 2014). Although the RT is considered as one of the predictors of success in karate sport, there are few studies addressing this issue (Chaabene et al., 2012). Furthermore, there is a noticeable inhomogeneity in findings among the studies published so far, as well as a diversity of the methodological approaches
(Mori et al., 2002; Chaabene et al. 2012; Mudric, Cuk, Nedeljkovic, Jovanovic, \& Jaric 2015).

In studies up to date, the focus of interest has mainly been on the comparison of the RT between the karate athletes of high level of training and the novices. When it comes to the SRT, Mori et al. (2002) have not found any significant differences between the black belt karate athletes and participants who haven't been involved in the karate training. In contrast to that, the results of later studies indicate that, regardless of the applied protocol, karate athletes on high level of training achieve shorter RT in comparison to novices (Tanaka et al., 2012; Mudric et al., 2015). On the other hand, the findings are in agreement when it comes to CRT. Elite karate athletes are significantly faster than the novices (Mudric et al., 2015) and non-athletes (Mori et al., 2002). However, it is interesting that the RT among the novices varies. So, the higher the informativeness about the position relative to the opponent, the shorter the RT (Tanaka et al., 2012). Additionally, the results of one study show that the athletes who had been training for a longer time and who are more experienced, need more time to respond, but make fewer mistakes when the CRT protocol is applied (Vences de Brito \& Silva, 2011). Assuming that the specific requirements of martial arts may influence the perceptual-motor abilities of athletes, Chen et al. (2017) compared two martial arts - taekwondo and karate (Chen et al., 2017). They hypothesized that combat, based on taekwondo kicks, may cause these athletes to develope faster perceptual processing than the karate athletes, in order to compensate for the longer time needed for movements of the lower limbs. SRT was used as a measurement of speed of perceptual processing and the significant differences were found between the groups compared, whereas the taekwondo athletes achieved better results for SRT.

The studies conducted in the field of motor control indicate that the RT increases with the complexity of the task (Haibach, Reid, \& Collier, 2011). Furthermore, some studies have confirmed the relation between CRT and levels of training in both genders. Such findings indicate that the athletes who achieve a faster CRT are closer to high-level performance in competitions (Heirani et al., 2012). A similar conclusion regarding karate athletes has been given by Mori et al.(2002), while a completely different perspective on the importance of RT in karate has been introduced by results of comparison of 
karate athletes from the regional to the international competition level. Using the multiple regression analysis Martinez de Quel et al. (2015) found that the competitive experience and the success are not an important predictors for CRT. Coskun et al. (2014.) also concluded that the athletes competitive status is not significantly related to SRT nor CRT (Coşkun, Koçak, \& Saritaş, 2014).

The study, conducted on the sample of an adult men and women in the Great Britain, confirms the correlation between the RT and age, whereas both the simple and the choice reaction time become longer and more variable after the late twenties. It is noticeable that the changes are nonlinear and that the tendency is more obvious for the SRT. Significant gender differences have also been identified. Not only are women slower in comparison to men, but also achieve more variable results. The differences are also more obvious for the CRT than for the SRT (Der \& Deary, 2006). Nevertheless, findings obtained on a sample of karate athletes suggest that gender is not significantly related to the RT, but a tendency is found for women to achieve a shorter RT than men (Vences de Brito \& Silva, 2011). Koskun et al. (2014) came to slightly different findings. They found that there were no differences between men and women when it came to SRT, but that significant differences existed for CRT in favor of men. A slight correlation between gender and CRT, in favor of men, was found by Martinez de Quel et al. (2015). The results of reaserch conducted by Ventes de Brito and Silva (2011) indicate that there are no significant differences in SRT achieved by karate athletes in relation to gender, age and level of training. Also, the only participants who had a remarkably longer CRT compared to others were those over 35 years of age.

Compared with adults, children achieve a slower simple and choice RT. In situations where a larger amount of information needs to be processed, the children are not only slower, but also less efficient. This could be due to the correlation between age and the information processing speed in any of the phases, but other factors may have an impact, too, such as the shorter attention span which children may have (Haibach et al., 2011). In this regard, the children involved in karate training may gain positive effects in development of cognitive functions. Some studies indicate that karate increases the development of cognitive functions, including the RT, the information processing speed, working memory and visual-motor coordination (Alesi et al., 2014). However, almost none of the studies addressing these issues deal with children of preadolescent and adolescent age. The possible correlation between the karate training and the RT among this population are indicated by the research that has confirmed a statistically significant difference for the SRT and the CRT in children between 10 and 12 years of age on one side, and juniors (16 and 17 years of age) and seniors (18+ years of age) on the other side. No significant differences were found between cadets (13-15 years of age) and juniors and seniors, but there is a noticeable tendency of decrease in RT relative to increase in years of age (Coşkun et al., 2014).

However, it remains unclear if there are any differences in SRT and CRT among karate athletes of preadolescent and early adolescent age, regardless of involment in the competition system. It also remains unknown whether there is a correlation between the RT and gender at this age. Additionally, no data dealing with the relative differences between SRT and CRT were obtained on the population of karate athletes. Therefore, the aim of this study was to determine whether the differences in simple and choice reaction time between preadolescent and early adolescent boys and girls at different levels of training existed, as well as to determine the relative differences between SRT and CRT depending on the level of training and gender.

\section{METHOD}

This is a cross-sectional study, and measuring were conducted using the field-test method. The data has been sampled using an RT testing software, custom developed for this research in LabVIEW 2012 software. The precision of software is expressed in $1 \mathrm{~ms}$ (Marković et al., 2019).

\section{Sample}

The study involved 78 participants, between 7 and 15 years of age (boys $\mathrm{n}=47$, average age $10.73 \pm 2.31$; girls $\mathrm{n}=31$, average age $11.41 \pm 2.12$ ), all of them being young karate athletes. The participants were divided according to gender and age, into four subsamples: boys in basic level of training (BBLT) 7-10, $n=31$ and boys in premastery level of training (BPMLT) 11- 
$15, \mathrm{n}=16$; and girls in basic level of training (GBLT) $7-10, \mathrm{n}=16$ and girls in premastery level of training (GPMLT) 11-15, $\mathrm{n}=15$. A criterion for establishing groups was defined in relation to the phases of the training process. Namely, the whole process of training until the achievinig mastery level can be divided into two phases: basic and pre-mastery. The first of them - the basic phase, involves learining the basic technique and achieving levels up to green belt, and usually refers to children up to 11 years of age. In the second phase - pre-mastery phase of training, students learn more complex technical elements, the combinations of blocks and punches and approach their pre-mastery belt exam. This period coincides with the age of 15 years.

Participants have been athletes involved in the training process three times a week in their karate club. None of them reported any visual difficulties or any other conditions that could interfere with the dominant hand function. The participants and their parents were aware of the purpose of the research and they voluntarily agreed to take part in it. The research has been realized in accordance with principals of The Declaration of Helsinki and with the approval of the Ethical Commision of the Faculty of Sport and Physical Education No. 484-2, University of Belgrade.

\section{Measurament}

The testing of the participants was carried out during February and March 2019. Prior to the testing, the participants were explained the procedures and shown the proper way of performing the tests. Each of the participants had had 2 trial attempts before the testing started.

Two reaction times were measured: simple and choice; and two different test protocols were used. The SRT test protocol consisted of 5 consecutive trials in wich the visual stimulus, represented by a light-green rectangle with a diameter of $15 \mathrm{~cm}$, was shown on a grey background of a laptop screen. The stimulus was shown at a randomized time interval between 5 to 15 seconds. The participants were asked to respond to the appearance of the stimulus as quickly as possible, by pressing the corresponding mouse button using the index finger. The SRT was measured starting the application of the visual stimulus and terminated by the pressing of the button on the mouse. Once the SRT has been terminated, the stimulus would be replaced by a grey background.
The CRT test protocol consisted of 5 consecutive trials in which the visual stimulus was represented by arrows pointing to the left or right, in a light-green square with a diameter of $15 \mathrm{~cm}$. The stimulus was, the same as in the case of SRT, presented on a gray background of the screen, at a randomized time interval of 5-15 seconds, and participants were asked to respond to the appearance of only one of the given stimuli (only left or right-oriented arrow), ignoring the other one. CRT was measured from the onset of stimulus emission, until the press of the mouse button.

All measurements were performed for the dominant hand and the mouse was adjusted for both left-handed and right-handed participants. The average value of the 3 best attempts was used in further data processing.

\section{Variables}

The reaction time was estimated by the following variables:

- SRT - simple reaction time (measured for the dominant hand) expressed in ms,

- CRT - choice reaction time (measured for the dominant hand) expressed in $\mathrm{ms}$ and

- $\Delta \mathrm{RT}$ - the difference between SRT and CRT expressed in \%.

\section{Statistical analysis}

A descriptive statistical procedure was applied in the current study and the following indicators were obtained: mean value (M), standard deviation $(S D)$, coefficient of variation (cV\%), minimum (Min) and maximum (Max). The normality of data distribution was verified using the KolmogorovSmirnov non-parametric test (K-S). The differences between the variables concerning gender and age of the participants and the combination of these two factors were examined by using two-way analysis of variance of different groups (Two-way ANOVA), while partial differences between defined subsamples were determined by application of post hoc tests using Bonferroni correction. All statistical procedures were conducted using the Microsoft Office Excel 2007 and IBM SPSS Statistics 20 software packages. The level of statistical significance was defined for the probability of $95 \%$, i.e. $\mathrm{p} \leq 0.05$. 


\section{RESULTS}

The descriptive indicators for the reaction time achieved on the SRT and CRT tests, as well as their relative difference are shown in the Table 1 . The results are presented at an overall level for both boys and girls. The normality of data distribution is confirmed by the results of the Kolmogorov-Smirnov test (Table 2). The descriptive indicators at the subsample level for boys and girls for SRT and CRT, as well as their relative difference are shown in the Table 3.

Table 1. The descriptive indicators for the reaction time for boys and girls.

\begin{tabular}{|c|c|c|c|c|c|}
\hline & & $\mathrm{AS} \pm \mathrm{SD}$ & cV\% & Min & Max \\
\hline \multirow{3}{*}{$\begin{array}{l}\text { Boys } \\
(n=47)\end{array}$} & SRT (ms) & $166.35 \pm 24.41$ & 14.67 & 124.67 & 220.67 \\
\hline & CRT (ms) & $261.39 \pm 61.13$ & 23.39 & 153.67 & 388.33 \\
\hline & $\Delta \mathrm{RT}(\%)$ & $34.12 \pm 12.24$ & 35.86 & 7.22 & 62.64 \\
\hline \multirow{3}{*}{$\begin{array}{l}\text { Girls } \\
(\mathrm{n}=31)\end{array}$} & $\mathrm{SRT}(\mathrm{ms})$ & $156.49 \pm 24.49$ & 15.65 & 110.67 & 216.00 \\
\hline & CRT (ms) & $244.19 \pm 49.43$ & 20.24 & 162.33 & 383.33 \\
\hline & $\Delta \mathrm{RT}(\%)$ & $34.77 \pm 7.55$ & 21.70 & 21.55 & 59.30 \\
\hline
\end{tabular}

Note: SRT - simple reaction time expressed in ms, CRT - choice reaction time expressed in ms, $\Delta$ RT - the difference between SRT and CRT expressed in \%.

Table 2. Results of the Kolmogorov-Smirnov goodness of fit test for SRT, CRT and $\Delta$ RT, in relation to gender and level of training

\begin{tabular}{|c|c|c|c|c|c|}
\hline \multicolumn{6}{|c|}{ Kolmogorov-Smirnov goodness of fit test } \\
\hline & & & Statistic & $d f$ & Sig. \\
\hline \multirow{6}{*}{$\begin{array}{c}\text { 7-10 } \\
\text { Basic level of training }\end{array}$} & \multirow{3}{*}{ Boys } & SRT & .118 & 31 & 0.200 \\
\hline & & CRT & .075 & 31 & 0.200 \\
\hline & & $\Delta \mathrm{RT}$ & .118 & 31 & 0.200 \\
\hline & \multirow{3}{*}{ Girls } & SRT & .188 & 16 & 0.136 \\
\hline & & CRT & .171 & 16 & 0.200 \\
\hline & & $\Delta \mathrm{RT}$ & .188 & 16 & 0.136 \\
\hline \multirow{6}{*}{$\begin{array}{c}7-10 \\
\begin{array}{c}\text { Premastery level of } \\
\text { training }\end{array}\end{array}$} & \multirow{3}{*}{ Boys } & SRT & .187 & 16 & 0.138 \\
\hline & & CRT & .175 & 16 & 0.200 \\
\hline & & $\Delta \mathrm{RT}$ & .109 & 16 & 0.200 \\
\hline & \multirow{3}{*}{ Girls } & SRT & .111 & 15 & 0.200 \\
\hline & & CRT & .167 & 15 & 0.200 \\
\hline & & $\Delta \mathrm{RT}$ & .216 & 15 & 0.058 \\
\hline
\end{tabular}


Table 3. Reaction time and reltive difference in SRT and CRT within sub-samples of boys and girls.

\begin{tabular}{|c|c|c|c|c|c|}
\hline \multirow{2}{*}{ Age (years) / Level of training } & & \multicolumn{2}{|c|}{ Boys } & \multicolumn{2}{|c|}{ Girls } \\
\hline & & $M$ & $S D$ & $M$ & $S D$ \\
\hline \multirow{3}{*}{$\begin{array}{c}\text { 7-10 } \\
\text { Basic level of training }\end{array}$} & SRT (ms) & 176.70 & 21.20 & 169.00 & 22.39 \\
\hline & CRT (ms) & 289.02 & 54.94 & 256.26 & 38.88 \\
\hline & $\Delta \mathrm{RT}(\%)$ & 36.75 & 13.67 & 33.50 & 6.22 \\
\hline \multirow{3}{*}{$\begin{array}{l}\text { 11-15 } \\
\text { Premastery level of training }\end{array}$} & SRT (ms) & 146.31 & 16.69 & 143.15 & 19.45 \\
\hline & CRT (ms) & 207.86 & 28.06 & 231.31 & 57.20 \\
\hline & $\Delta \mathrm{RT}(\%)$ & 29.03 & 6.62 & 36.12 & 8.76 \\
\hline
\end{tabular}

Note: SRT - simple reaction time expressed in ms, CRT - choice reaction time expressed in ms, $\Delta$ RT - the difference between SRT and CRT expressed in \%.

The results of two-way analysis of variance (twoway ANOVA) at the overall level confirmed that there was no statistically significant difference of the results for the SRT variable in comparison with Gender $\left(F_{(1,74)}=1.27, p=0.262\right)$, as well as no interaction between the factors Gender and Training Level $\left(F_{(1,74)}\right.$ $=0.224, p=0.638)$, but also a statistically significant difference in scores for the SRT variable relative to the Training Level $\left(F_{(1,74)}=34.28, \mathrm{n}^{2}=0.31, p=0.000\right)$. Further analysis and application of a series of post hoc tests using Bonferroni correction confirmed that there were statistically significant differences between the groups within subsamples of boys $(M D=30.38$, $S D=24.41, \mathrm{p}=0.000)$ in favour of the participants at the pre-master level of training, as well as between the groups within subsamples of girls $(M D=25.84, S D=$ $24.49, p=0.001)$ in favour of the participants at the pre-master level of training (Graph 1).

The results of two-way analysis of variance (twoway ANOVA) at the overall level confirmed that there was no statistically significant difference of the results for the CRT variable in comparison with Gender $\left(F_{(1,74)}=0.16, p=0.683\right)$, but that there is a statistically significant difference in CRT values relative to the factor Level of Training $\left(F_{(1,74)}=21.78, \mathrm{n}^{2}=0.22, p\right.$ $=0.000)$, as well as the interaction of factors Gender and Training Level $\left(F_{(1,74)}=6.11, \mathrm{n}^{2}=0.07, p=0.016\right)$. Further analysis and application of a series of post hoc tests using Bonferoni correction confirmed that there were statistically significant differences between the groups within subsample of boys $(M D=81.16, S D$ $=61.13, p=0.000$ ), in favour of the participants on the pre-mastery level of training, but not between the groups within subsamples of girls $(M D=24.95, S D=$ $49.43, p=0.153)$. Statistically significant differences were also found between subsamples of boys and girls at basic level of training (7-10 years of age) ( $M D$ $=32.76, S D=52.03, p=0.030)$, but not at the premastery level of training (11-15 years of age) $(M D=$ 23.45, $S D=45.41, p=0.179)($ Graph 1$)$. 


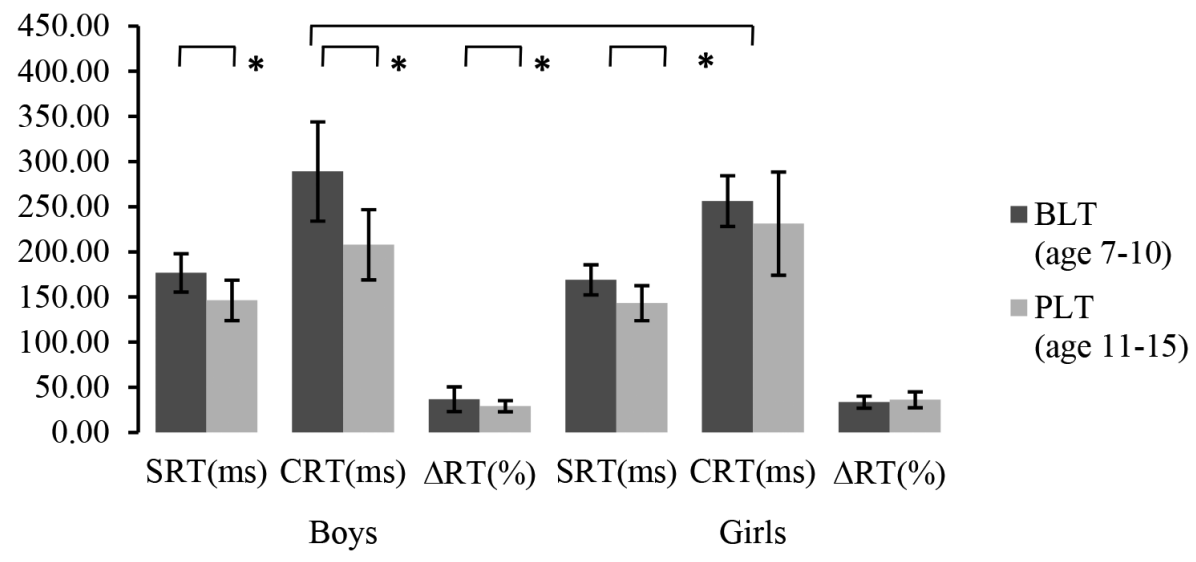

Note: SRT - simple reaction time expressed in ms, CRT - choice reaction time expressed in ms, $\Delta$ RT - the difference between SRT and CRT expressed in $\%,{ }^{*}$ level of statistical significance defined for the $\mathrm{p} \leq 0.05$, BLT - basic level of training, PLT - premastery level of training.

Graph 1. Analysis of reaction time for the two tests and their relative differences, for a sample of boys and girls.

The results of two-way analysis of variance (twoway ANOVA) at the overall level confirmed that there was no statistically significant difference of the results for the $\Delta \mathrm{BP}$ variable in comparison with Gender $\left(F_{(1,74)}=0.61, p=0.434\right)$ and Level of Training $\left(F_{(1,74)}\right.$ $=1.08, p=0.301)$, but also confirmed that there is an interaction of the factors Gender and Training Level $\left(F_{(1,74)}=4.46, \mathrm{n}^{2}=0.05, p<0.038\right)$. The application of a series of post hoc tests using Bonferoni correction confirmed that there were statistically significant differences between the groups within subsample of boys $(M D=7.71, S D=12.24, p=0.018)$, in favour of the participants at the pre-mastery level of training (Graph 1).

\section{DISCUSSION}

The aim of current study was to determine whether the differences in simple and choice reaction time between boys and girls of preadolescent and early adolescent age existed, as well as the differences between the participants on the basic and premastery level of karate training. Two-factor analysis of variance revealed that there are no statistically significant differences in relation to gender for SRT, which is in agreement with previous studies on the sample of karate athletes (Coşkun, et al., 2014;
De Brito \& Silva, 2011). Statistically significant difference in SRT was determined within subsamples between BBLT and BRMLT, and GBLT compared to the GPMLT, in favour of the karate athletes on the higher level of training. The findings are in partial agreement with the Ventes de Brito and Silva study (2011) who found that athletes at the basic level of training responded more slowly to a simple stimulus than those at the pre-mastery level, but that these differences were not statistically significant. The cause of the disagreement between the findings obtained may be explained by the age of the participants. Namely, in the aforementioned study, the participants at the basic level of training ( $26 \pm 10$ years) were on average older than those at pre-mastery level of training ( $21 \pm 9$ years), but also at the age when the fastest RT is achieved (Pierson \& Montoye, 1958). On the other hand, the karate athletes included in this study were children of preadolescent and early adolescent age, who were still in the process of growth and development that imply constant changes. In this case, when it comes to RT, these changes are represented by the reduction of the response time to a simple stimulus among the older in comparison with the younger participants (Iida, Miyazaki, \& Uchida, 2010). Bearing this in mind, it is not entirely clear whether the statistically significant difference found between the subsamples of this study is due to training, development process, or a combination of these two factors. 
However, a comparison of the results obtained in this study with those reported by Coşkun et al. (2014), provides a different perspective on the training process and its possible impact on SRT. Namely, Coşkun et al. (2014) found that competitors between 10 and 12 years of age achieved significantly longer SRT $(0.160 \pm 0.037 \mathrm{~ms})$ compared to juniors $(0.138$ $\pm 0.039 \mathrm{~ms})$ and seniors $(0.130 \pm 0.032 \mathrm{~ms})$, but no significant difference was found when compared with cadets $(0.144 \pm 0.035 \mathrm{~ms})$. It can be assumed that the training based on practicing of skills needed for the acquirement of karate levels could be the cause of the differences between the participants in this research, i.e. that the early involvement into the competition system is the cause of the absence of differences in the research of Coşkun et al.. Namely, the early involvement into the competition system remarkably changes the training process and shifts its focus from technical to tactical oriented training. In other words, the focus of young athletes involved in competition system shifts from learning the correct technical forms at different stages of complexity, in controlled conditions, to more intense stimulation of reaction to the actions of opponents in free conditions. In this way, the mechanisms which are developed gradually and at a slower pace in the usual training system, are triggered early in childhood. In this case, pre-adolescent and early adolescent children are exposed to stimuli which are usually characteristic for adolescence or even adulthood.

Although findings of this study are in accordance with the findings of Mudric et al. (2015), that karate athletes who are at a higher level of training achieve a shorter SRT compared to novices, the different methodological approaches raise more questions. In the aforementioned research, the offensive karate techniques were used as stimuli and the defence techniques were used as the response. Such a setting leaves room for speculations, given that the participants were karate athletes with at least ten years of competitive experience on the one hand, and novices on the other. In other words, the differences between the experienced competitors and the novices cannot be explained by the level of training alone. Namely, some research shows that the expert advantage is most obvious in tasks that are similar to real conditions in which the sport-specific perceptual skills are assessed (Mori, et al., 2002). So, when it comes to anticipation, it has been confirmed that the ability of prediction results in reduction of RT (Thomas, Gallagher, \&
Purvis, 1981). It is reasonable to say that anticipation, as a learning effect (Schmidt, 1968), depends on the level of training, i.e. it is possible to avoid a backlog in RT, at the expense of anticipation, that occurs in situations where conventional RT tests are used (Schmidt, 1968). In order to minimize the effect of anticipation, the non-karate tasks were used in this study. The test applied has provided such conditions, so it can be stated with greater certainty that the obtained results are not influenced by perceptualcognitive expertise. However, the question about the extent to which the RT is the result of different level of training, maturation, or a combination of these two factors remains unanswered. A future research which would compare a larger sample of participants, in relation to gender, age, level of training and competitive orientation might answer the question more precisely. Finally, a complete understanding of these processes is not possible without research of RT among the inactive population, as well as comparison between the karate and the athletes from other sports.

With regard to CRT, statistically significant differences were found for the interaction of the factors Gender and Level of Training. Namely, at the basic level of training, girls achieve significantly shorter CRT compared to boys. Therefore, it can be said that resultsof this study partially confirm previously published findings. They are in agreement with the previous studies which suggested that there are significant differences in CRT in relation to gender (Coşkun, Koçak, \& Saritaş, 2014; Der, \& Deary, 2016), but not with findings that were in favor of male participants. No tendency to maintain differences in later age, at a higher level of training was confirmed.

It can be assumed that in the basic phase of training the impact of training is not yet fully revealed as the training program is aimed at less complex moving tasks that are performed in simplified conditions and without partners. So, it can be assumed that the natural processes of maturing have a more significant impact at this stage, in which boys and girls show varying degrees of cognitive maturity. That is, girls, at the expense of maturation process, achieve faster information processing than boys, and therefore significantly shorter RT. This assumption is based on previous studies that have confirmed that girls achieve shorter RT than boys in pre-adolescent and early adolescent age (Fulton \& Hubbard, 1975), and that the difference for CRT is constantly increasing with the increasing number of alternative stimuli, in favour of girls (Fairweather, 1976). 
At the pre-mastery level of training, the focus of training becomes oriented towards partner, learning more complex technical forms and provoking neural, physical and behavioral mechanisms at different levels. The fact that an adequate stimulation in the appropriate period of development contributes to synaptogenesis is not an unfamiliar fact (Knudsen, 2004), and that specific operations in sensory periods promote better performance and larger changes in the corresponding areas of the brain (Penhune, 2011). The potential impact of training during this period can, therefore, be discussed based on the results obtained. Even though the importance of the maturation process should by no means be ignored, the obtained results could indicate that the influence of training during this period is gaining primacy. Accordingly, the absence of differences could be attributed to the training process and the reduction of $\mathrm{RT}$ among boys to the maturing process. The results of comparison between the subgroups give us the indications of how the gender-related differences are manifested. The statistically significant differences were found between boys BBLT $(289.02 \pm 54.94 \mathrm{~ms})$ and BPMLT (207.86 $\pm 28.06 \mathrm{~ms})$, while they are nonexistent between girls. Even though GBLT (256.26 \pm $38.88 \mathrm{~ms}$ ) achieve slower CRT in comparison with GPMLT $(231.31 \pm 57.20 \mathrm{~ms})$, these differences are not as emphasized as among boys.

When it comes to boys, the relative difference between SRT and CRT, expressed in percentage, decreases in the early adolescence, which coincides with the pre-mastery level of training. In that period $\Delta \mathrm{RT}$ is $29.03 \pm 6.62 \%$, opposite to $36.75 \pm 13.67 \%$ noted on the basic level of training. Meanwhile, a different tendency is found among girls. The difference increases among the participants at the pre-mastery level of training. The $\Delta \mathrm{RT}$ on the basic level of training totals $33.50 \pm 6.22 \%$, while it reaches $36.12 \pm 8.76 \%$ on the pre-mastery level of training. It should bebe emphasized, however, that statistical significance was confirmed only on the sub-sample of boys, not girls. The results obtained for $\Delta \mathrm{RT}$ may be an indicator of puberty influence, but also a combination of the training and maturing process. No statistically significant gender-related differences were found for $\Delta \mathrm{RT}$. When it comes to boys, the findings suggest that the relative difference decreases due to the decrease in CRT, which becomes significantly shorter in the premastery level of training. It appears, therefore, that they are making dramatic improvement, comparedto girls who are more balanced in the progress. Besides, another conclusion that can be made is that there is a tendency of a constant shortening of SRT and CRT among girls, while this is not the case among boys.

It can be assumed that these findings are due to the different response of a boysgirlsa to the tasks of the training process. The differences in technical and tactical inventiveness, which are expressed in a sports fight later on, are a starting point for the speculation about creative problem solving. Men show approximately 50\% greater tendency towards counterattack (Tabben et al., 2015) - a tactical form which requires a high level of inventiveness relative to the opponent's activity, displayed in a short time interval. However, a more detailed analysis of these findings exceeds the scope of this study, but it certainly leaves significant space for future research.

\section{CONCLUSION}

Based on the data analysis and in accordance with the defined objectives, it can be concluded that the SRT findings of this study are in accordance with the results obtained in the previous studies. It has been confirmed that there are no significant differences in SRT between boys and girls. On the other hand, significant differences were found between karate athletes on the basic and pre-mastery level of training (BBLT compared with BPMLT; and GBLT compared with GPMLT), in favour of the athletes at higher level of training. Such findings can only partially verify the results of the previous research, and the reason for this could be searched within the differences in methodological approaches that limit the theoretical speculation and require cautious in comparison of data and drawing conclusions. Namely, the criteria for the sample classification in the aforenamed studies were not the same (competitive categories, the level of competitive success, the level of training where novices are compared with mastery level karate athletes, competitors or a sample which hasn't been involved in the training process). Besides, the age of the subject covered the period from the preadolescent age to adulthood. Also, it should not be overlooked that the experimental conditions were not even and that the various stimuli were used when performing the tests for SRT and CRT (from computer-generated stimuli to specific karate techniques). 
It cannot be stated with absolute certainty whether the acquired differences are the consequence of karate training, the maturation process or the overlap of these two factors. The problem becomes even more complex, consequencely to the fact that an increasing number of children in the early stages of development are involved in the karate competition system. This fact is supported by a growing number of youth competitions organized by the World Karate Federation (WKF), as well as redefinition of the competition rules relative to ages below the cadet level. Some future research should therefore take this aspect into acount, too, paying attention to the participants competitive orientation. In that context, the research should examine the influence of SRT and CRT in relation to competitive success.

Taking the gender-related differences at basic level of training for CRT into account, the findings of this study are in a partial accordance with the results obtained in the previous studies. Namely, the statistical significance was confirmed in favour of girls in comparison with boys of preadolescent age at the basic level of training. However, it remains unclear whether the differences identified in this study were caused by the process of maturation or training, which is at this, basic level, simplified and performed in facilitated conditions. On the other hand, pre-mastery level of training is remarkably more complex and to a greater extent focused on the practice with a partner. Besides, the differences found at the sub-sample of boys (and their absence on the sub-sample of girls) do not provide a sufficient basis for speculation about the impact of training on the gender-related differences in results.

While observing the relative difference between SRT and CRT, the tendencies noticed among boys and girls differ. Statistically significant reduce in $\Delta \mathrm{RT}$ can be noticed among boys at pre-mastery

\section{REFERENCES}

1. Alesi, M., Bianco, A., Padulo, J., Vella, F. P., Petrucci, M., Paoli, A., Palma, A., \& Pepi, A. (2014). Motor and cognitive development: the role of karate. Muscles, Ligaments and Tendons Journal, 4(2), 114-120.

2. Atan, T., \& Akyol, P. (2014). Reaction times of different branch athletes and correlation between level of training. As opposed to this, $\Delta \mathrm{RT}$ increases relative to the level of training among girls, but the differences are not of statistical significance. When it comes to boys, the results suggest that the differences identified are due to the decrease in CRT, which decreases remarkably among boys at the premastery level of training. Bearing in mind that the participants were children of preadolescent and early adolescent age, the identified changes can be basically attributed to the process of maturation. It remains to be explored how large the role of the training process in the identified changes is, and whether it manifests differently among boys and girls.

It is important to remember that the research of the differences in RT among karate athletes, classified by level of training, age, competitive status (e.g. age categories, competition level, discipline etc.), as well as comparison with the physically active and inactive population - assume research problems which are followed by specifics that require a cautious methodological setup. Even though the existence of differences related to the level of training is partially confirmed by this study, the sensitivity of participants developmental period suggests further research. For this reason, the exact extent of influence of the training process at different levels of training needs to be assessed more precisely, as well as the influence of maturing process on RT, by including a control group of children who have not received a karate training along with the children of preadolescent and early adolescent age involved in other sports.

\section{Acknowledgements}

This study is a part of the project "The Effects of Applied Physical Activity on Locomotor, Metabolic, Psycho-Social and Educational Status of the Population of the Republic of Serbia", No. III47015, and was funded by The Ministry of Education, Science and Technological Development of the Republic of Serbia - Scientific Projects 2011 - 2019. reaction time parameters. Procedia-Social and Behavioral Sciences, 116, 2886-2889.

3. Chaabène, H., Hachana, Y., Franchini, E., Mkaouer, B., \& Chamari, K. (2012). Physical and physiological profile of elite karate athletes. Sports Medicine, 42, 829-843. 
4. Chen, W. Y., Wu, S. K., Song, T. F., Chou, K. M., Wang, K. Y., Chang, Y. C., \& Goodbourn, P. T. (2017). Perceptual and motor performance of combat-sport athletes differs according to specific demands of the discipline. Perceptual and Motor Skills, 124(1), 293-313.

5. Coşkun, B., Koçak, S., \& Saritaş, N. (2014). The comparison of reaction times of karate athletes according to age, gender and status. Science, Movement and Health, 14(2), 213-217.

6. Der, G., \& Deary, I. J. (2006). Age and sex differences in reaction time in adulthood: Results from the united kingdom health and lifestyle survey. Psychology and Aging, 21(1), 62-73.

7. Fairweather, H. (1976). Sex differences in cognition. Cognition, 4(3), 231-280.

8. Fulton, C. D., \& Hubbard, A. W. (1975). Effect of puberty on reaction and movement times. Research Quarterly. American Alliance for Health, Physical Education and Recreation, 46(3), 335344.

9. Haibach, P., Reid, G., \& Collier, D. (2011). Motor Learning and Development. Champaign: Human Kinetics.

10. Heirani, A., Vazini Taher, A., Soori, Z., \& Rahmani, M. (2012). Relationship between choice reaction time and expertise in team and individualsports: A gender differences approach. Australian Journal of Basic and Applied Sciences, 6(8), 344348.

11. Iida, Y., Miyazaki, M., \& Uchida, S. (2010). Developmental changes in cognitive reaction time of children aged 6-12 years. European Journal of Sport Science, 10(3): 151-158.

12. Jensen A. (2006), Clocking the mind: Mental chronometry and individual differences, Elsevier, Amsterdam.

13. Kimura, D. (2000). Sex and Cognition. MIT press.

14. Knudsen, E. I. (2004). Sensitive periods in the development of the brain and behavior. Journal of Cognitive Neuroscience, 16(8), 1412-1425.

15. Marković, S., Valdevit, Z., Bon, M., Pavlović, Lj., Ivanović, J., \& Dopsaj, M. (2019). Differences in visual reaction characteristics in national level cadet and junior female handball players. Facta Universitatis Series: Physical Education and Sport, 17(1), 69-78.
16. Martinez de Quel, O., Bennett, S. J., Lopez-Adan, E., Zapico, A. G., \& Saucedo-Morales, F. (2015). Choice reaction time is not related to competition success in karate combat. European Journal of Human Movement, 35, 41-50.

17. Mori, S., Ohtani, Y., \& Imanaka, K. (2002). Reaction times and anticipatory skills of karate athletes. Human Movement Science, 21, 213-230.

18. Mudric, M., Cuk, I., Nedeljkovic, A., Jovanovic, S., \& Jaric, S. (2017). Evaluation of Video-based method for the measurement of reaction time in specific sport situation. International Journal of Performance and Analysis in Sport, 15(3), 10771089.

19. Müller, S., \& Abernethy, B. (2012). Expert anticipatory skill in striking sports: A review and a model. Research Quarterly for Exercise and Sport, 83(2), 175-187.

20. Nuri, L., Shadmehr, A., Ghotbi, N., \& Moghadam, B. A. (2012). Reaction time and anticipatory skill of athletes in open and closed skill-dominated sport. European Journal of Sport Science, 13, 431436.

21. Penhune, V. B. (2011). Sensitive periods in human development: evidence from musical training. Cortex, 47(9), 1126-1137.

22. Pierson, W. R., \& Montoye, H. J. (1958). Movement time, reaction time, and age. Journal of Gerontology, 13, 418-421.

23. Schmidt, R. A. (1968). Anticipation and timing in human motor performance. Psychological Bulletin, 70(6p1), 631-646.

24. Schmidt, R. A., \& Lee, T. D. (1998). Motor Control and Learning. Champaign: Human Kinetics.

25. Tabben, M., Coquart, J., Chaabene, H., Franchini, E., Ghoul, \& N., Tourny, C. (2015). Time-motion, tactical and technical analysis in toplevel karatekas according to gender, match outcome and weight categories. Journal of Sports Sciences, 33(8), 841-849.

26. Tanaka, K., Hasegawa, M., Kataoka, T., \& Katz, L. (2010). The effect of self-position and posture information on reaction time. International Journal of Computer Science in Sport, 9(3), 4-14.

27. Thomas, J.R., Gallagher, J.D., \& Purvis, G.J. (1981). Reaction time and anticipation time: Effects of development. Research Quarterly for Exercise and Sport, 52(3), 359-367. 
Vuković, V., et al., Differences Between Simple and Choice..., PHYSICAL CULTURE 2019; 73 (2): 238-249

28. Vences de Brito, A., \& Silva, C. (2011). Reaction time in karate athletes. IDO Movement for Culture. Journal of Martial Arts Anthropology, 11(4): 35-39.
29. Youngen, L. (1959). A comparison of reaction and movement times of women athletes and nonathletes. Research Quarterly. American Association for Health, Physical Education and Recreation, 30(3), 349-355.

Submitted: 07.08.2019.

Accepted: 07.09. 2019.

Published Online First: 01.11.2019. 


\title{
РАЗЛИКЕ ПРОСТОГ И ИЗБОРНОГ ВРЕМЕНА РЕАКЦИЈЕ КОД МЛАДИХ КАРАТИСТА ОБА ПОЛА РАЗЛИЧИТОГ НИВОА ОБУЧЕНОСТИ
}

\author{
Весна Вуковић ${ }^{1}$, Стефан Марковић ${ }^{1}$, Ненад Коропановски르, Мирослав Миловановић ${ }^{1}$, Миливој Допсај $^{3}$ \\ ${ }^{1}$ Факултет спорта и физичког васпитања, Универзитет у Београду, студент ДАС, Србија \\ ${ }^{2}$ Криминалистичко - полицијски универзитет у Београду, Србија \\ ${ }^{3}$ Факултет спорта и физичког васпитања, Универзитет у Београду, Србија \\ ${ }^{3}$ Институт за спорт, туризам и услуге, Јужно-Уралски Универзитет, Чељабинск, Русија
}

\begin{abstract}
Сажетак
У поређењу са одраслима, деца имају спорије просто (ПВР) и изборно (ИВР) време реакције (ВР) на просту и изборну визуелну драж. На основу података из доступне литературе, може се закључити да би разлог могла бити повезаност година старости са брзином обраде информација, али и да други фактори, попут слабије пажње, на пример, могу имати утицаја. Нека истраживања показују да карате фаворизује развој когнитивних функција, укључујући и ВР. Стога је циљ ове студије био да утврди да ли између дечака и девојчица преадолесцентског и раног адолесцентског узраста, на ученичком и предмајсторском степену обуке у каратеу, постоје разлике за просто и изборно време реакције.Тестирано је 78 испитаника подељених у четири субгрупе, у односу на пол и степен обучености, применом посебно дизајнираног софтвера за мерење BP, развијеног у програмском пакету LabVIEW 2012. Двофакторском анализом варијансе (Two-way ANOVA) утврђено је да нема разлика између резултата дечака и девојчица остварених за ПВР, али да су оне значајне на нивоу субузорака по критеријуму мајсторства. Када је у питању ИВР, разлике су утврђене на нивоу субузорка дечака, као и између полова на ученичком нивоу обуке. Не може се са сигурношћу тврдити да ли су добијене разлике последица тренинга или неких других физиолошко-когнитивних феномена, односно процеса сазревања. Стога би будућа истраживања морала да обухвате шири узорак - популацију неактивне, као и деце укључене у друге спортове.
\end{abstract}

Кључне речи: ВРЕМЕ РЕАКЦИЈЕ / НИВО ОБУЧЕНОСТИ / ДЕЦА / КАРАТЕ /

\section{УВОД}

Максимална брзина кретања није приоритет у свим спортовима, алисемаксимално брза реакција углавном сматра важним фактором успешности (Vencesde Brito \& Silva, 2011). Способност уочавања и екстракције битних информација у условима временских и просторних ограничења представља квалитативну разлику у остваривању резултата између спортиста различитог нивоа тренираности (Heirani, Vazini Taher, Soori, \& Rahmani 2012; Mori, Ohtani, \& Imanaka, 2002; Müller \& Abernethy, 2012). Такође, распрострањено је уверење да је брзина реакције у каратеу једна од детерминанти успеха (Chaabene, Hachana, Franchini, Макоuer, \& Chamari 2012; Vencesde Brito \& Silva, 2011; Mori et al., 2002). С тим у вези, сматра се да би тренажни задаци засновани на што краћем времену реаговања на активност противника, могли да воде ка развоју вештине перцепције и неспецифичних базичних сензорних функција каратиста (Mori et al., 2002; de Brito \& Silva, 2011).

Време реакције (BР) дефинише се као мера брзине перцептивно-когнитивног система (Jensen, 2006),изражена кроз време које протекне од појаве стимулуса до одговора (Heirani et al., 2012). Истраживачи разликују два основна типа BP: прости и изборни. Просто време реакције подразумева један одговор на један стимулус, у познатим условима и што краћем времену. Изборно време реакције представља што је 
Вуковић В., и сар., Разлике простог и изборног времена..., ФИЗИЧКА КУЛТУРА 2019; 73 (2): 238-248

могуће бржу реализацију моторног одговора у ситуацији када постоји и алтернативни стимулус (Schmidt \& Lee, 1999). Специфичност спорта утиче на развој сензорно-когнитивних вештина (Nuri, Shadmehr, Ghotbi \& Moghadam, 2012), a неспортисти упоређењу са спортистима остварују дуже BP (Tanaka, Hasegawa, Kataoka \& Katz, 2010; Youngen, 1959), било да је реч о визуелном или аудитивном стимулусу (Atan \& Akyol, 2014). Независно од тога да ли је у истраживањима примењен стимулус специфичан за спорт (нпр. за спорт карактеристична техника) или не, спортисти су остваривали краће ВР за моторни одговор (Tanaka et al., 2012; Youngen, 1959; Atan \& Akyol, 2014). И поред тога што се ВР сматра једним од предиктора успешности у каратеу, мали је број студија које се баве овим проблемом (Chaabene et al., 2012). Шта више, међу до сада публикованим истраживањима, приметна је нехомогеност налаза, али и разноликост у методолошком приступу (Mori et al., 2002; Chaabene et al., 2012; Mudric, Cuk, Nedeljkovic, Jovanovic, \& Jaric 2015).

у досадашњим истраживањима тежиште интересовања углавном је било на испитивању ВР каратиста високог нивоа обучености и почетника. Када је у питању просто време реакције (ПВР), Мори и сар. (2002) нису установили значајне разлике између каратиста носилаца црног појаса и испитаника који нису били у карате тренажном процесу. Супротно томе, резултати каснијих истраживања указују да каратисти високог степена обучености, без обзира на примењени протокол, константно остварују краће време реакције у односу на почетнике (Tanaka et al., 2012; Mudric et al., 2015). С друге стране, постоји сагласност налаза када је реч о изборном времену реакције (ИВР). Карате експерти су значајно бржи од почетника у обуци (Mudric et al., 2015) и неспортиста (Mori et al., 2002). Интересантно је, међутим, да ВР код почетника варира. Па тако, што је информативност о позицији у односу на противника већа - краће je BP (Tanaka et al., 2012). Такође, резултати једне студије указују да спортистима који тренирају дуже и имају више искуства, треба више времена за одговор, али и да праве мање грешака када је примењен протокол за ИВР (Vencesde Brito \& Silva, 2011). Полазећи од претпоставке да специфични захтеви борилачког спорта могу да утичу на перцептивно-моторичке способности спортиста, Чен и сар. (2017) поредили су два борилачка спорта - теквондо и карате (Chen et al., 2017). Претпоставили су да спортска борба, која је у теквондоу базирана на ножним ударцима, може довести до тога да ови спортисти развијају бржу перцептивну обраду у односу на каратисте како би компензовали дуже време неопходно за покретање доњих екстремитета. ПВР коришћено је као мера брзине перцептивне обраде, а значајне разлике утврђене су између поређених група, на рачун бољих резултата за ПВР које су остварили теквондисти.

Студије у области моторне контроле указују да ce ВР повећава са сложеношћу задатка (Haibach, Reid, \&Collier,2011). Такође, појединаистраживања потврдила су повезаност између ИВР и нивоа обучености код оба пола. Овакви налази указују да су спортисти који остварују брже ИВР ближи такмичарским перформансама високог нивоа (Heirani et al., 2012). Сличан закључак изводе Мори и сар. (2002) када су у питању каратисти, док сасвим другачију перспективу на значај ВР у каратеу дају резултати поређења каратиста од регионалног до међународног такмичарског нивоа. Наиме, Мартинез де Кел и сар. (2015) утврдили су вишеструком регресионом анализом да такмичарско искуство и успех нису значајни предиктори ИВР (Martinezde Quel et al., 2015). Да такмичарски статус спортиста није у значајној вези са ПВР и ИВР закључују и Кошкун и сар. (2014) (Coşkun, Koçak, \& Saritaş, 2014).

Истраживање изведено на узорку одраслих мушкараца и жена у Великој Британији, потврђује повезаност ВР са годинама, те да након касних двадесетих време реакције, како просто тако и изборно, постаје дуже и варијабилније. Приметно је да су промене нелинеарне, као и да је таква тенденција више изражена за ПВР. Утврђене су и значајне разлике између полова. Жене, не само да су спорије у односу на мушкарце, већ су њихови резултати и варијабилнији. Такође, разлике су више изражене за ИВР него за ПВР (Der \& Deary, 2006). Ипак, налази истраживања добијени на узорку каратиста, наводе на закључак да пол није значајно повезан са ВР, али се уочава тенденција да жене остварују краће ВР у односу на мушкарце (Vences de Brito \& Silva, 2011). Кошкун и сар. (2014) дошли су до нешто другачијих сазнања. Утврдили су, наиме, да између мушкараца и жена нема разлика када је у питању ПВР, али да значајне разлике постоје за ИВР у корист мушкараца. 
Слабу повезаност између пола и ИВР, у корист мушкараца, утврдили су Мартинез де Кел и сар. (2015). Резултати истраживања Вентес де Брита и Силве (2011) указују да између каратиста различитог пола, узраста и нивоа обучености нема значајних разлика за остварено ПВР. Такође, једино испитаници старији од 35 година имају значајно дуже ИВР у односу на остале.

У поређењу са одраслима, деца остварују спорије просто и изборно ВР. У ситуацијама када већа количина информација захтева обраду, деца не само да су спорија, већ су и мање ефикасна. Разлог може бити повезаност година старости са брзином обраде информација у било којој фази, али и други фактори, попут слабије пажње на пример, могу имати утицаја (Haibach et al., 2011). C тим у вези, деца укључена у програм вежбања каратеа могла би остварити позитивне ефекте када је у питању развој когнитивних функција. Наиме, нека истраживања показују да карате поспешује развој когнитивних функција, укључујући и ВР, брзину обраде информација, радну меморију и визуелно-моторну координацију (Alesi et al., 2014). Међутим, студија које се баве овим проблемима код деце преадолесцентског и адолесцентског узраста, готово да нема. Назнаке о могућој повезаности карате тренинга са ВР код ове популације дају резултати истраживања којим је утврђена значајна разлика за ПВР и ИВР између деце узраста 10-12 година са једне стране те, јуниора (16 и 17 г.) и сениора (18+ г.) са друге.Такође, нису утврђене значајне разлике између кадета (13-15 г.), јуниора и сениора, али је приметно константно скраћење ВР у односу на повећање година старости (Coşkun et al., 2014).

Свакако остаје непознаница да ли код каратиста, преадолесцената и раних адолесцената, независно од укључености у систем такмичења, постоје разлике за ПВР и ИВР. Такође, није познато да ли у том узрасту постоји повезаност између ВР и пола. Осим тога, нема података добијених на популацији каратиста који се баве релативном разликом између ПВР и ИВР. Стога је циљ овог истраживања био да утврди да ли између дечака и девојчица преадолесцентског и раног адолесцентског узраста, на различитом степену обуке, постоје разлике за просто и изборно време реакције, као и да утврди колике су релативне разлике између ПВР и ИВР у зависности од нивоа обуке и пола.

\section{МЕТОД РАДА}

Ово истраживање је трансверзалног карактера. Мерења су реализована применом методе теренског тестирања. Подаци су узорковани коришћењем софтвера за тестирање ВР, развијеног за потребе овог истраживања, у програмском пакету LabVIEW 2012. Прецизност софтвера изражена је у 1 ms (Marković et al., 2019).

\section{Узорак}

У истраживању је учествовало 78 испитаника, старости од 7 до 15 година (дечака $n=47$, просечне старости $10.73 \pm 2.31$; девојчица $n=31$, просечне старости $11.41 \pm 2.12$ ), младих каратиста. Испитаници су подељени у односу на пол и узраст, на четири субузорка: дечаци у ученичкој обуци (ДЧУО) 7-10, $n=31$ и дечаци у предмајсторској обуци (ДЧПО) $11-15, n=16$; и девојчице у ученичкој обуци (ДВУО) 7-10, $n=16$ и девојчице у предмајсторској обуци (ДВПО) 11-15, $n=15$. Критеријум за формирање група дефинисан је у односу на фазе тренажног процеса. Наиме, обука вежбача до стицања мајсторског звања може се поделити у две фазе: ученичку и предмајсторску. Прва - ученичка фаза обуке, подразумева учење основне технике, стицање звања до зеленог појаса и одговара узрасном добу до 11 година. У другој - предмајсторској фази обуке, вежбачи уче сложеније техничке елементе, комбинације блокова и удараца, и приближавају се мајсторском испиту. Тај период подудара се са узрастом до 15 година.

Сви испитаници су били вежбачи укључени у тренажни процес три пута недељно у свом карате клубу. Нико од испитаника није пријавио да има визуелне сметње, нити стање које би ометало функцију доминантне руке. Испитаници и њихови родитељи су били упознати са циљем истраживања и добровољно су пристали да у њему учествују. Истраживање је реализовано у складу са постулатима Хелсиншке декларације и уз одобрење Етичке комисије Факултета спорта и физичког васпитања, број 484-2, Универзитета у Београду. 
Вуковић В., и сар., Разлике простог и изборног времена..., ФИЗИЧКА КУЛТУРА 2019; 73 (2): 238-248

\section{Методе мерења}

Тестирање испитаника обављено је у периоду фебруар - март 2019. године. Пре почетка тестирања, испитаницима су објашњени процедуре и начин извођења тестова. Испитаници су пре тестирања имали по два пробна покушаја.

Мерена су два времена реакције: просто и изборно; а коришћена су два различита тест протокола. Протокол испитивања ПВР састојао се од 5 узастопних мерења у којима је визуелни стимулус чинио квадрат светлозелене боје, пречника $15 \mathrm{~cm}$, презентован на сивој позадини екрана лаптопа. Стимулус је презентован у рандомизованом временском интервалу од 5 до 15 секунди. Од испитаника је захтевано да на појаву сигнала реагују у што краћем времену притиском кажипрста на тастер миша. ПВР мерено је од почетка емитовања визуелног стимулуса и прекидано је притиском на тастер миша, након чега би стимулус поново био замењен сивом позадином.

Протокол испитивања ИВР састојао се од 5 узастопних мерења у којима су визуелни стимулус чиниле стрелице усмерене у леву или десну страну, у квадрату светлозелене боје пречника 15 $\mathrm{cm}$. Стимулус је, као и случају ПВР, презентован на сивој позадини екрана у рандомизованом временском интервалу од 5 до 15 секунди, а од испитаника је захтевано да реагују на појаву само једног одговарајућег стимулуса (само лево или само десно оријентисане стрелице), игноришући други. ИВР мерено је од почетка емитовања стимулуса до притиска тастера миша.

Сва мерења извршена су за доминантну руку, а миш је био прилагођен и леворуким и десноруким испитаницима. Средња вредност 3 најбоља покушаја коришћена је у даљој обради података.

\section{Варијабле}

Време реакције процењено је следећим варијаблама:

- ПВР - просто време реакције (мерено за доминантну руку) изражено у ms,

- ИВР - изборно време реакције (мерено за доминантну руку) изражено у $\mathrm{ms}$ и

- $\triangle \mathrm{BP}$ - разлика између ПВР и ИВР изражена $\mathrm{y} \%$.

\section{Статистичка анализа}

У овом раду примењена је дескриптивна статистичка процедура којом су добијени следећи показатељи: аритметичка средина (M), стандардна девијација (SD), коефицијент варијације ( $\mathrm{cV} \%)$, минимум (Min) и максимум (Max). Нормалност дистрибуције података проверена је применом непараметријског теста Колмогоров-Смирнов (K-S). Применом двофакторске анализе варијансе различитих група (Two-way ANOVA) испитиване су разлике између варијабли у односу на пол и узраст испитаника и комбинацију ова два фактора, док су за утврђивање парцијалних разлика субузорка коришћени пост хок тестови уз примену Бонферони корекције. Све статистичке процедуре извршене су програмским пакетима Microsoft Office Excel 2007 и IBM SPSS Statistics 20. Ниво значајности био је дефинисан за вероватноћу од $95 \%$, односно $p \leq 0.05$.

\section{РЕЗУЛТАТИ}

Табела 1 приказује дескриптивне показатеље за време реакције остварене на тестовима ПВР и ИВР, као и за њихову релативну разлику. Резултати су приказани на генералном нивоу за дечаке и девојчице. Резултати Колмогоров-Смирнов теста потврдили су нормалност дистрибуције података (Табела 2). У Табели 3 приказани су дескриптивни показатељи на нивоу субузорака дечака и девојчица за ПВР и ИВР, као и за њихову релативну разлику. 
Вуковић В., и сар., Разлике простог и изборног времена..., ФИЗИЧКА КУлТУРА 2019; 73 (2): 238 -248

Табела 1 Дескриптивни показатељи за време реакције, за дечаке и девојчице

\begin{tabular}{|c|c|c|c|c|c|}
\hline & & $\mathrm{AS} \pm \mathrm{SD}$ & cV\% & Min & $\operatorname{Max}$ \\
\hline \multirow{3}{*}{$\begin{array}{c}\text { Дечаци } \\
(n=47)\end{array}$} & ПВР (ms) & $166.35 \pm 24.41$ & 14.67 & 124.67 & 220.67 \\
\hline & ИВР (ms) & $261.39 \pm 61.13$ & 23.39 & 153.67 & 388.33 \\
\hline & $\Delta \mathrm{BP}(\%)$ & $34.12 \pm 12.24$ & 35.86 & 7.22 & 62.64 \\
\hline \multirow{3}{*}{$\begin{array}{c}\text { Девојчице } \\
\quad(n=31)\end{array}$} & ПВР (ms) & $156.49 \pm 24.49$ & 15.65 & 110.67 & 216.00 \\
\hline & ИВР (ms) & $244.19 \pm 49.43$ & 20.24 & 162.33 & 383.33 \\
\hline & $\Delta \mathrm{BP}(\%)$ & $34.77 \pm 7.55$ & 21.70 & 21.55 & 59.30 \\
\hline
\end{tabular}

Легенда: ПВР - просто време реакције изражено у милисекундама, ИВР - изборно време реакције изражено у милисекундама, $\Delta$ ВР - релативна разлика између ПВР и ИВР изражена у процентима.

Табела 2 Резултати Колмогоров-Смирнов теста нормалности дистрибуције података за ПВР, ИВР и $\Delta \mathrm{BP}$, за дечаке и девојчице на ученичком и предмајсторском нивоу обуке

\begin{tabular}{|c|c|c|c|c|c|}
\hline \multicolumn{6}{|c|}{ Колмогоров-Смирнов тест } \\
\hline & & & Statistic & $d f$ & Sig. \\
\hline \multirow{6}{*}{$\begin{array}{c}7-10 \\
\text { Ученички } \\
\text { ниво обуке }\end{array}$} & \multirow{3}{*}{ Дечаци } & ПВР & .118 & 31 & 0.200 \\
\hline & & ИВР & .075 & 31 & 0.200 \\
\hline & & $\Delta \mathrm{BP}$ & .118 & 31 & 0.200 \\
\hline & \multirow{3}{*}{ Девојчице } & ПВР & .188 & 16 & 0.136 \\
\hline & & ИВР & .171 & 16 & 0.200 \\
\hline & & $\Delta \mathrm{BP}$ & .188 & 16 & 0.136 \\
\hline \multirow{6}{*}{$\begin{array}{c}\text { 7-10 } \\
\text { Предмајсторски } \\
\text { ниво обуке }\end{array}$} & \multirow{3}{*}{ Дечаци } & ПВР & .187 & 16 & 0.138 \\
\hline & & ИВР & .175 & 16 & 0.200 \\
\hline & & $\Delta \mathrm{BP}$ & .109 & 16 & 0.200 \\
\hline & \multirow{3}{*}{ Девојчице } & ПВР & .111 & 15 & 0.200 \\
\hline & & ИВР & .167 & 15 & 0.200 \\
\hline & & $\Delta \mathrm{BP}$ & .216 & 15 & 0.058 \\
\hline
\end{tabular}

Табела 3 Време реакције и релативна разлика ПВР и ИВР, на нивоу субузорака дечака и девојчица

\begin{tabular}{|c|c|c|c|c|c|}
\hline \multirow{2}{*}{ Узраст (год.) / Ниво обуке } & & \multicolumn{2}{|c|}{ Дечаци } & \multicolumn{2}{|c|}{ Девојчице } \\
\hline & & $M$ & $S D$ & $M$ & $S D$ \\
\hline \multirow{3}{*}{$\begin{array}{c}\text { 7-10 } \\
\text { Ученички }\end{array}$} & ПВР (ms) & 176.70 & 21.20 & 169.00 & 22.39 \\
\hline & ИВР (ms) & 289.02 & 54.94 & 256.26 & 38.88 \\
\hline & $\Delta \mathrm{BP}(\%)$ & 36.75 & 13.67 & 33.50 & 6.22 \\
\hline \multirow{3}{*}{$\begin{array}{c}\text { 11-15 } \\
\text { Предмајсторски }\end{array}$} & ПВР (ms) & 146.31 & 16.69 & 143.15 & 19.45 \\
\hline & ИВР (ms) & 207.86 & 28.06 & 231.31 & 57.20 \\
\hline & $\Delta \mathrm{BP}(\%)$ & 29.03 & 6.62 & 36.12 & 8.76 \\
\hline
\end{tabular}

Легенда: ПВР - просто време реакције изражено у милисекундама, ИВР - изборно време реакције изражено у милисекундама, $\Delta \mathrm{BP}$ - релативна разлика између ПВР и ИВР изражена у процентима. 
Вуковић В., и сар., Разлике простог и изборног времена..., ФИЗИЧКА КУЛТУРА 2019; 73 (2): 238-248

Резултати двофакторске анализа варијансе (twoway ANOVA) на генералном нивоу показали су да нема статистички значајне разлике резултата за варијаблу ПВР у односу на Пол $\left(F_{(1,74)}=1.27\right.$, $p=0.262)$, као и да нема интеракције фактора Пол и Ниво обуке $\left(F_{(1,74)}=0.224, p=0.638\right)$, али да постоји статистички значајна разлика у резултатима за варијаблу ПВР у односу на Ниво обуке $\left(F_{(1,74)}=\right.$ $\left.34.28, \mathrm{n}^{2}=0.31, p=0.000\right)$. Даљом анализом и применом серије пост хок тестова уз Бонферони корекцију, утврђено је да постоје статистички значајне разлике између субузорака дечака $(M D=$ $30.38, S D=24.41, \mathrm{p}=0.000)$ у корист испитаника на предмајсторском нивоу обуке, као и између субузорака девојчица $(M D=25.84, S D=24.49, p=0.001)$ у корист испитаника на предмајсторском нивоу обуке (Графикон 1).

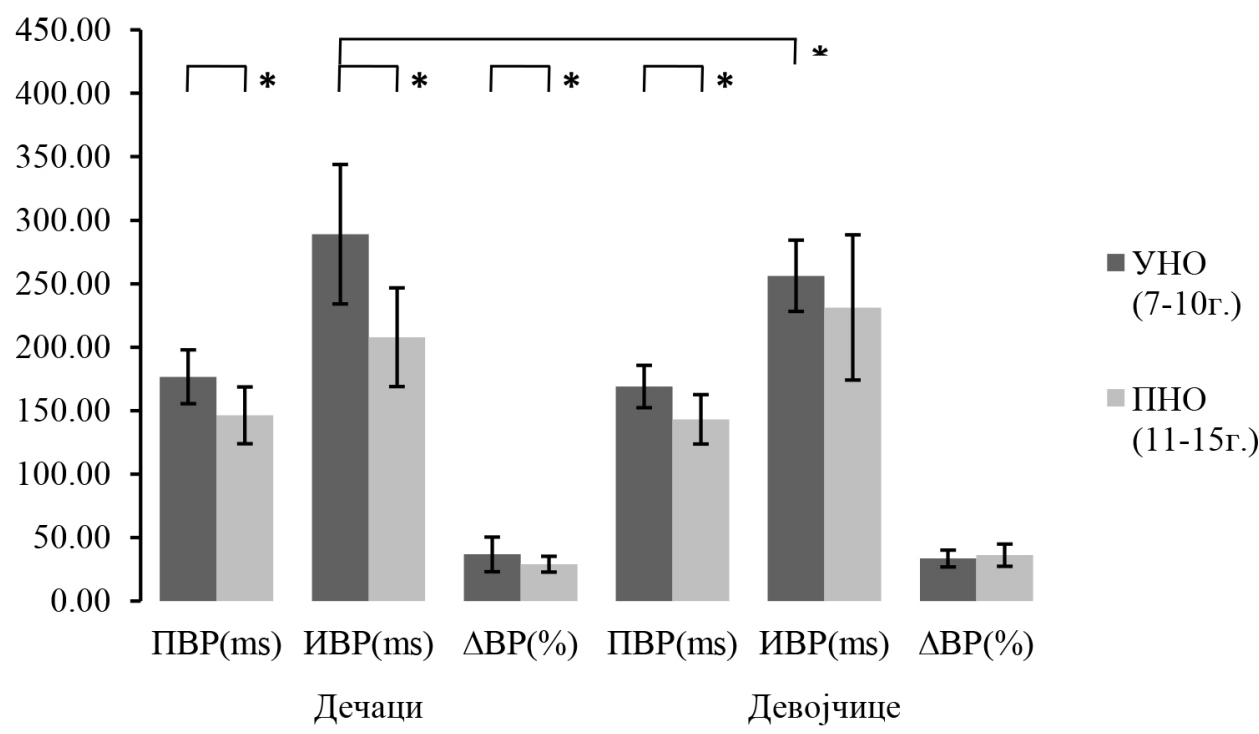

Легенда: ПВР - просто време реакције изражено у милисекундама, ИВР - изборно време реакције изражено у милисекундама, $\triangle \mathrm{BP}$ - релативна разлика између ПВР и ИВР изражена у процентима, * ниво значајности дефинисан за $\mathrm{p} \leq 0.05$, УНО - ученички ниво обуке, ПНО - предмајсторски ниво обуке.

Графикон 1 Анализа времена реакције на два теста и њихове релативне разлике, на субузорку дечака и девојчица

Резултати двофакторске анализа варијансе (two-way ANOVA) на генералном нивоу показали су да нема статистички значајне разлике вредности ИВР у односу на Пол $\left(F_{(1,74)}=0.16, p=\right.$ $0.683)$, али да постоји статистички значајна разлика вредности ИВР у односу на фактор Ниво обуке $\left(F_{(1,74)}=21.78, \mathrm{n}^{2}=0.22, p=0.000\right)$, као и да постоји интеракција фактора Пол и Ниво обуке $\left(F_{(1,74)}=6.11, \mathrm{n}^{2}=0.07, p=0.016\right)$. Даљом анализом и применом серије пост хок тестова уз Бонферони корекцију, утврђено је да постоје статистички значајне разлике између субузорака дечака (MD $=81.16, S D=61.13, p=0.000)$, у корист испитаника на предмајсторском нивоу обуке, али не и субузорака девојчица $(M D=24.95, S D=49.43, p=$ 0.153). Такође, утврђене су статистички значајне разлике између субузорака дечака и девојчица на ученичком нивоу обуке (7-10 година старости) $(M D=32.76, S D=52.03, p=0.030)$, али не и на предмајсторском нивоу обуке (узраст 11-15 година) $(M D=23.45, S D=45.41, p=0.179)$ (Графикон 1).

Резултати двофакторске анализа варијансе (two-way ANOVA) за варијаблу $\Delta$ ВР показали су да на генералном нивоу нема статистички значајних разлика вредности $\triangle$ ВР у односу на Пол $\left(F_{(1,74)}=0.61, p=0.434\right)$ и Ниво обуке $\left(F_{(1,74)}=1.08\right.$, $p=0.301)$, али да постоји интеракција фактора Пол и Ниво обуке $\left(F_{(1,74)}=4.46, \mathrm{n}^{2}=0.05, p<0.038\right)$. Применом серије пост хок тестова уз Бонферони корекцију, утврђено је да постоје статистички значајне разлике између субузорака дечака $(M D=$ $7.71, S D=12.24, p=0.018)$, у корист испитаника на предмајсторском нивоу обуке (Графикон 1). 


\section{ДИСКУСИЈА}

Циљ овог истраживања био је да утврди да ли између каратиста преадолесцентског и раног адолесцентског узраста оба пола, на ученичком и предмајсторском нивоу обуке, постоје разлике за просто и изборно време реакције. Двофакторском анализом варијансе утврђено је да нема статистички значајних разлика између полова за ПВР, што је у сагласности са досадашњим истраживањима на узорку каратиста (Coşkun et al., 2014; De Brito \& Silva, 2011). Статистичка значајност разлика за ПВР утврђена је на нивоу субузорака овог истраживања, код ДЧУО у односу на ДЧПО, као и код ДВУО у односу на ДВПО, у корист каратиста на вишем степену обуке. Добијени налази у делимичној су сагласности са студијом Вентес де Брито и Силва (2011) који су утврдили да вежбачи, на ученичком нивоу обуке спорије реагују на прост стимулус у односу на оне на предмајсторском нивоу, али и да ове разлике нису статистички значајне. Узрок несагласности добијених налаза може се тражити у узрасту испитаника. Наиме, у споменутој студији, испитаници у фази ученичке обуке (26 \pm 10 година) били су у просеку старији од оних у предмајсторској обуци (21 \pm 9 година), али у животној доби када се постиже најбрже BP (Pierson \& Montoye, 1958). С друге стране, каратисти обухваћени овим истраживањем, били су деца преадолесцентског и раног адолесцентског узраста, у процесу раста и развоја који подразумева константне промене. Конкретно, када је ВР у питању, те промене огледају се у скраћењу времена реакције на прост стимулус са повећањем година старости (Iida, Miyazaki, \& Uchida, 2010). Имајући то у виду, није сасвим јасно да ли је статистички значајна разлика утврђена између субузорака у овој студији последица обуке, развојног процеса или комбинације ова два фактора.

Ипак, поређење добијених резултата овог истраживања са онима које пријављују Кошкун и cap. (2014), омогућава другачији поглед на процес обуке и његов потенцијални утицај на ПВР. Наиме, Кошкун и сар. (2014) утврдили су да такмичари узраста 10-12 година остварују значајно дуже ПВР $(0.160 \pm 0.037 \mathrm{~ms})$ у односу на јуниоре $(0.138$ $\pm 0.039 \mathrm{~ms})$ и сениоре $(0.130 \pm 0.032 \mathrm{~ms})$, али да нема значајности када се упореде са кадетима узраста 13-15 година (0.144 $\pm 0.035 \mathrm{~ms})$. Могуће је претпоставити да је тренажни процес заснован на обуци за карате звања узрок евидентираних разлика испитаника у овом истраживању, односно да је рани улазак у систем такмичења узрок одсуства разлика у истраживању Кошкун и сар. Наиме, рани улазаку систем такмичења у значајној мери мења тренажни процес и преусмерава га са техничке на тактичку обуку. Другим речима, фокус младих вежбача се помера са учења коректних техничких форми у различитим стадијумима сложености, у контролисаним условима, ка интензивнијој стимулацији реакције на деловање противника у слободним условима спортске борбе. На тај начин се код деце већ у раном периоду провоцирају механизми који се у уобичајеном систему обуке развијају поступно и нешто спорије. Деца преадолесцентског и раног адолесцентског узраста стога бивају изложена тренажним стимулусима карактеристичним за адолесцентско или чак одрасло доба.

Иако резултати ове студије потврђују налазе Мудрића и сар. (2015), да каратисти који су на вишем нивоу обучености остварују краће ПВР у односу на почетнике, различити методолошки приступи отварају још нека питања. У споменутом истраживању, као стимулуси су коришћене офанзивне, а као одговор дефанзивне карате технике карактеристичне за спортску борбу. Ако се има у виду да су испитаници били каратисти ca најмање десетогодишњим такмичарским искуством у борбама са једне стране, и почетници у обуци са друге - таква поставка оставља простор за спекулације. Другим речима, евидентирана разлика између експерата и почетника не може бити објашњена само нивоом обуке. Наиме, истраживања показују да се експертска предност најочитије изражава у задацима који су слични реалним условима у којима се процењују за спорт специфичне перцептивне вештине (Mori et al., 2002). Дакле, када је реч о антиципацији, потврђено је да предвиђање догађаја резултује скраћењем BP (Thomas, Gallagher, \& Purvis, 1981). Разумно је рећи да антиципација, као ефекат учења (Schmidt, 1968) зависи од нивоа обучености. Другим речима, на рачун антиципације могуће је избећи заостатак у ВР који се јавља у ситуацијама када се примењују уобичајени тестови за ВР (Schmidt, 1968). Стога, да бисмо на минимум свели антиципацију, испитанике смо тестирали 
Вуковић В., и сар., Разлике простог и изборног времена..., ФИЗИЧКА КУЛТУРА 2019; 73 (2): 238-248

у задацима неспецифичним за карате. Такви су услови остварени примењеним тестом, па са већом сигурношћу можемо тврдити да добијени резултати нису под утицајем перцептивнокогнитивне експертизе. Ипак, остаје питање у којој мери је остварено ВР последица различитог нивоа обуке, сазревања или комбинације ова два фактора. Јаснији одговор могло би дати неко будуће истраживање у којем би се упоредио већи узорак испитаника груписаних према полу и узрасту, односно степену обуке и такмичарској оријентацији. Најзад, потпуно разумевање ових процеса није могуће без истраживања ВР код неактивне популације, али и поређења вежбача из различитих спортова.

Када је у питању ИВР, утврђене су статистички значајне разлике за интеракцију фактора Пол и Ниво обуке. Наиме, на ученичком нивоу обуке девојчице остварују статистички значајно краће ИВР у односу на дечаке. Стога можемо рећи да резултати ове студије делимично потврђују до сада публиковане налазе. Они су у сагласности са досадашњим истраживањима која упућују на постојање значајних разлика у ИВР између полова (Coşkun, Koçak, \& Saritaş, 2014; Der \& Deary, 2016), али не и са налазима у корист испитаника мушког пола. Такође, не уочава се тенденција очувања разлика у каснијем узрасном добу, на вишем нивоу обуке.

Може се претпоставити да у ученичкој фази утицај тренинга јошувек ниједовољно изражен јер је програм обуке усмерен на мање сложене кретне задатке који се изводе у олакшаним условима и без партнера. Другим речима, може се претпоставити да значајнији утицај у овој фази имају природни процеси сазревања, у којима девојчице и дечаци показују различит степен когнитивне зрелости. Односно, да девојчице на рачун сазревања, остварују бржу обраду информација у односу на дечаке, а самим тим и значајно краће ВР. Оваква претпоставка утемељена је на досадашњим истраживањима која потврђују да девојчице у односу на дечаке у преадолесцентском и раном адолесцентском узрасту остварују краће ВР (Fulton \& Hubbard, 1975), те да се разлика за ИВР константно повећава са бројем алтернативних стимулуса, у корист девојчица (Fairweather, 1976).

На предмајсторском нивоу обуке, мења се усмереност тренинга који је у већој мери оријен= тисан на рад са партнером, учење сложенијих техничких форми и провокацију неуралних, физичких и бихевијоралних механизама на различитим нивоима. Није непознато да адекватна стимулација у одговарајућем развојном периоду доприноси синаптогенези (Knudsen, 2004), те да специфично деловање у сензибилним периодима потпомаже бољим перформансама и већим променама у одговарајућим областима мозга (Penhune, 2011). Стога се, на основу добијених резултата може спекулисати о потенцијалном утицају тренинга у том периоду. Иако се процес сазревања никако не сме занемарити, добијени резултати би могли представљати назнаке да утицај тренинга у том периоду добија примат. У том смислу одсуство разлика могло би се приписати тренажном процесу, а скраћење ВР код дечака процесу сазревања. Назнаке о томе како су ови утицаји изражени по половима, дају резултати поређења субгрупа. Док су код дечака утврђене статистички значајне разлике између ДЧУО (289.02 $\pm 54.94 \mathrm{~ms})$ и ДЧПО (207.86 \pm 28.06 $\mathrm{ms})$, код девојчица оне изостају. Иако ДВУО $(256.26 \pm 38.88 \mathrm{~ms})$ имају спорије ИВР у односу на ДВПО (231.31 $\pm 57.20 \mathrm{~ms})$, ове разлике нису тако изражене као код дечака.

Релативна разлика између ПВР и ИВР изражена у процентима се, када су дечаци у питању, смањује у раном адолесцентском периоду, који се подудара са предмајсторским нивоом обуке. У том периоду $\Delta$ ВР износи $29.03 \pm 6.62 \%$, наспрам $36.75 \pm 13.67 \%$ евидентираних на ученичком нивоу обуке. Код девојчица, међутим, уочава се другачија тенденција. Разлика се код испитаника на предмајсторском нивоу обуке повећава. На ученичком нивоу $\Delta$ ВР износи $33.50 \pm 6.22 \%$, да би на предмајсторском нивоу достигла $36.12 \pm$ 8.76\%. Треба, међутим, нагласити да је статистичка значајност потврђена само на субузорку дечака, али не и девојчица. Добијени резултати за $\Delta \mathrm{BP}$ могу бити показатељ утицаја пубертетског периода, али и комбинација тренажног и процеса сазревања. У односу на пол за $\Delta \mathrm{BP}$ нису утврђене статистички значајне разлике. Када су дечаци у питању, добијени налази наводе на закључак да релативна разлика опада на рачун смањења ИВР које, код дечака на предмајстарском нивоу обуке, постаје значајно краће. Чини се, дакле, да они остварују скоковит напредак, у односу на девојчице код којих је овај процес уједначенији. И не само то. Закључује се да код девојчица постоји 
Вуковић В., и сар., Разлике простог и изборног времена..., ФИЗИЧКА КУЛТУРА 2019; 73 (2): 238-248

тенденција уједначеног скраћења ПВР и ИВР, док код дечака то није случај.

Може се претпоставити да су овакви налази последица различитог одговора дечака и девојчица на задатке тренажног процеса. Основ за спекулације на рачун креативности у решавању постављених задатака огледа се у разликама у техничко-тактичкој инвентивности коју у каснијем периоду изражавају у слободној спортској борби. То се види у, приближно 50\%, већој склоности мушкараца ка контранападу (Tabben et al., 2015) - тактичкој форми која захтева висок степен инвентивности у односу на противничку активност, исказану у кратком временском периоду. Детаљнија анализа ових резултата, ипак, превазилази оквире овог рада, али свакако представља значајан простор за будућа истраживања.

\section{ЗАКЉУЧАК}

У складу са постављеним циљевима, а на основу анализе података може се закључити да су налази ове студије за ПВР конзистентни са резултатима добијеним у претходним истраживањима. Потврђено је да нема статистички значајних разлика у ПВР између дечака и девојчица. С друге стране, утврђене су значајне разлике између вежбача на ученичком и предмајсторском нивоу обуке (ДЧУО у односу на ДЧПО; као и ДВУО у односу на ДВПО), у корист искуснијих каратиста. Такви налази делимично потврђују досадашња истраживања, а разлог томе може се потражити у различитим методолошким приступима који ограничавају простор теоријских спекулација и налажу пажљиво поређење резултата и извођење закључака. Наиме, критеријуми за класификацију узорка у поменутим истраживањима нису били исти (такмичарске категорије, ниво такмичарске успешности, степен обуке где се почетници пореде са каратистима на мајсторском нивоу, такмичарима или популацијом која није била у карате тренажном процесу). Поред тога, узраст испитаника обухватио је период од преадолесцентског до зрелог доба. Такође, не сме бити занемарено да експериментални услови нису били унифицирани, те да су примењени различити стимулуси приликом извођења тестова за ПВР и ИВР (од компјутерски генерисаних стимулуса до специфичних карате техника).

Не може се са сигурношћу тврдити да ли су добијене разлике у овом истраживању последица тренинга у каратеу или процеса сазревања, односно преклапања та два фактора. Додатно усложњавање проблема долази из чињенице да је све већи број деце, у раним фазама развоја, укључен у систем такмичења у каратеу. Томе у прилог говоре све бројнија такмичења за младе, организована под окриљем Светске карате федерације (World Karate Federation - WKF), као и редефинисање такмичарског правилника у складу са узрастом испод кадетског нивоа. Стога би неко будуће истраживање морало да узме у обзир и овај аспект каратеа, обраћајући пажњу и на такмичарску оријентацију. У том смислу, ваљало би испитати значај простог и изборног ВР за такмичарски успех.

Имајући у виду разлике између полова нађене за ИВР код вежбача на ученичком нивоу обуке, резултати ове студије делимично потврђују досадашње налазе. Наиме, статистичка значајност потврђена је у корист девојчица у односу на дечаке преадолесцентског узраста на ученичком нивоу обуке. Није сасвим јасно, међутим, да ли су разлике утврђене овом студијом проистекле на рачун процеса сазревања или тренинга који се на ученичком нивоу одликује једноставношћу и изводи у олакшаним условима. Односно, тренинга који је на предмајсторском нивоу значајно сложенији и, у већој мери, усмерен на рад са партнером. Такође, разлике добијене на нивоу субузорка дечака (те њихов изостанак на нивоу субузорка девојчица), не дају довољно основа за спекулације колики је удео тренинга у добијеним резултатима у односу на пол.

Када се посматра релативна разлика између ПВР и ИВР, уочавају се другачије тенденције код дечака и девојчица. Наиме, код дечака се примећује статистички значајно смањење $\Delta \mathrm{BP}$ на предмајсторском у односу на ученички ниво обуке. Супротно томе, код девојчица се $\Delta \mathrm{BP}$ повећава у односу на ниво обуке, али разлике нису статистички значајне. Када је реч о дечацима, резултати нас наводе на закључак да су уочене промене превасходно последица значајног смањења ИВР на предмајстарском нивоу обуке. Имајући у виду да су испитаници били деца преадолесцентског и раног адолесцентског узраста, може се рећи 
Вуковић В., и сар., Разлике простог и изборног времена..., ФИЗИЧКА КУЛТУРА 2019; 73 (2): 238-248

да су евидентиране промене у основи засноване на процесу сазревања. Ипак, остаје да се испита колики је удео тренажног програма у утврђеним променама, те да ли се он различито манифестује код дечака и девојчица.

Важно је имати у виду да истраживање разлика у ВР код каратиста, диференцираних према различитом нивоу обуке, узрасту, такмичарском статусу (нпр. узрасне такмичарске категорије, ниво такмичења, такмичарска дисциплина и сл.), те поређење са активном и неактивном популацијом - подразумевају истраживачке проблеме праћене специфичностима које захтевају пажљиву методолошку поставку. Иако је овом студијом делимично потврђено постојање разлика у односу на ниво обуке, осетљивост развојног

\section{ЛИТЕРАТУРА}

1. Alesi, M., Bianco, A., Padulo, J., Vella, F. P., Petrucci, M., Paoli, A., Palma, A., \& Pepi, A. (2014). Motor and cognitive development: the role of karate. Muscles, Ligaments and Tendons Journal, 4(2), 114-120.

2. Atan, T., \& Akyol, P. (2014). Reaction times of different branch athletes and correlation between reaction time parameters. Procedia-Social and $\mathrm{Be}$ havioral Sciences, 116, 2886-2889.

3. Chaabène, H., Hachana, Y., Franchini, E., Mkaouer, B., \& Chamari, K. (2012). Physical and physiological profile of elite karate athletes. Sports Medicine, 42, 829-843.

4. Chen, W. Y., Wu, S. K., Song, T. F., Chou, K. M., Wang, K. Y., Chang, Y. C., \& Goodbourn, P. T. (2017). Perceptual and motor performance of combat-sport athletes differs according to specific demands of the discipline. Perceptual and Motor Skills, 124(1), 293-313.

5. Coşkun, B., Koçak, S., \& Saritaş, N. (2014). The comparison of reaction times of karate athletes according to age, gender and status. Science, Movement and Health, 14(2), 213-217.

6. Der, G., \& Deary, I. J. (2006). Age and sex differences in reaction time in adulthood: Results from the united kingdom health and lifestyle survey. Psychology and Aging, 21(1), 62-73. периода у коме се налазио узорак, упућује на додатна истраживања. Наиме, неопходно је јасније проценити величину утицаја тренажног процеса на различитом нивоу обуке и испитати утицај сазревања на ВР укључивањем контролне групе нетрениране деце, као и деце преадолесцентског и раног адолесцентског узраста из других спортова.

\section{НАПОМЕНА}

Овај рад део је пројекта "Ефекти примењене физичке активности на локомоторни, метаболички, психо-социјални и васпитни статус популације Републике Србије", број III47015, финансираног од стране Министарства просвете, науке и технолошког развоја Републике Србије - научни пројекти, циклус 2011-2019.

7. Fairweather, H. (1976). Sex differences in cognition. Cognition, 4(3), 231-280.

8. Fulton, C. D., \& Hubbard, A. W. (1975). Effect of puberty on reaction and movement times. Research Quarterly. American Alliance for Health, Physical Education and Recreation, 46(3), 335344.

9. Haibach, P., Reid, G., \& Collier, D. (2011). Motor Learning and Development. Champaign: Human Kinetics.

10. Heirani, A., Vazini Taher, A., Soori, Z., \& Rahmani, M. (2012). Relationship between choice reaction time and expertise in team and individualsports: A gender differences approach. Australian Journal of Basic and Applied Sciences, 6(8), 344348.

11. Iida,Y., Miyazaki, M., \& Uchida, S. (2010). Developmental changes in cognitive reaction time of children aged 6-12 years. European Journal of Sport Science, 10(3), 151-158.

12. Jensen A. (2006). Clocking the mind: Mental chronometry and individual differences, Elsevier, Amsterdam.

13. Kimura, D. (2000). Sex and Cognition. MIT press.

14. Knudsen, E. I. (2004). Sensitive periods in the development of the brain and behavior. Journal of Cognitive Neuroscience, 16(8), 1412-1425. 
15. Marković, S., Valdevit, Z., Bon, M., Pavlović, Lj., Ivanović, J., \& Dopsaj, M. (2019). Differences in visual reaction characteristics in national level cadet and junior female handball players. Facta Universitatis Series: Physical Education and Sport, 17(1), 69-78.

16. Martinez de Quel, O., Bennett, S. J., Lopez-Adan, E., Zapico, A. G., \& Saucedo-Morales, F. (2015). Choice reaction time is not related to competition success in karate combat. European Journal of Human Movement, 35, 41-50.

17. Mori, S., Ohtani, Y., \& Imanaka, K. (2002). Reaction times and anticipatory skills of karate athletes. Human Movement Science, 21, 213-230.

18. Mudric, M., Cuk, I., Nedeljkovic, A., Jovanovic, S., \& Jaric, S. (2017). Evaluation of Video-based method for the measurement of reaction time in specific sport situation. International Journal of Performance and Analysis in Sport, 15(3), 10771089.

19. Müller, S., \& Abernethy, B. (2012). Expert anticipatory skill in striking sports: A review and a model. Research Quarterly for Exercise and Sport, 83(2), 175-187.

20. Nuri, L., Shadmehr, A., Ghotbi, N., \&Moghadam, B. A. (2012). Reaction time and anticipatory skill of athletes in open and closed skill-dominated sport. European Journal of Sport Science, 13, 431436.

21. Penhune, V. B. (2011). Sensitive periods in human development: evidence from musical training. Cortex, 47(9), 1126-1137.
22. Pierson, W. R., \& Montoye, H. J. (1958). Movement time, reaction time, and age. Journal of Gerontology, 13, 418-421.

23. Schmidt, R. A. (1968). Anticipation and timing in human motor performance. Psychological Bulletin, 70(6p1), 631-646.

24. Schmidt, R.A., \& Lee, T. D. (1998). Motor Control and Learning.Champaign: Human Kinetics.

25. Tabben, M., Coquart, J., Chaabene, H., Franchini, E., Ghoul, \& N., Tourny, C. (2015). Time-motion, tactical and technical analysis in toplevel karatekas according to gender, match outcome and weight categories. Journal of Sports Sciences, 33(8), 841-849.

26. Tanaka, K., Hasegawa, M., Kataoka, T., \& Katz, L. (2010). The effect of self-position and posture information on reaction time. International Journal of Computer Science in Sport, 9(3), 4-14.

27. Thomas, J.R., Gallagher, J.D., \& Purvis, G.J. (1981). Reaction time and anticipation time: Effects of development. Research Quarterly for Exercise and Sport, 52(3), 359-367.

28. Vences de Brito, A., \& Silva, C. (2011). Reaction time in karate athletes. IDO Movement for Culture. Journal of Martial Arts Anthropology, 11(4), 35-39.

29. Youngen, L. (1959). A comparison of reaction and movement times of women athletes and nonathletes. Research Quarterly. American Association for Health, Physical Education and Recreation, 30(3), 349-355. 